Indonesian Journal of Islamic Psychology

Volume 2. Number 2, December 2020 (p-ISSN: 2685-1482 e-ISSN 2714-7576)

website: http://e-journal.iainsalatiga.ac.id/index.php/ijip/index

\title{
Penerapan Psikologi Kognitif Dalam Mengolah Berita Hoax Di Media Sosial Selama Pandemi Covid-19 Di Kampung Santren Surabaya
}

\section{Sofia Zaini Kulbi ${ }^{*}$}

Pasca Sarjana Universitas Islam Negeri Sunan Ampel Surabaya, Indonesia

\begin{abstract}
Hoax news is considered to be an important problem faced by society today. Along with the covid-19 pandemic, it is possible for someone who is not responsible to misuse social media to spread hoax news about the Covid-19 pandemic for personal benefit. So, the understanding and processing information on social media requires cognitive abilities that each individual must have. This paper will discuss cognitive psychology, covid-19, and the characteristics and types of hoax news. Then the analysis of this paper is to describe how the application of cognitive thinking in processing hoax news during the covid-19 pandemic. The results of this analysis are that people do not get caught up in hoax news, there are 3 stages of cognitive thinking in processing hoax news during the Covid-19 pandemic, the first is the conceptual framework of thinking in seeing news, the second is thinking logically and critically in analyzing news, and third is making decisions on a news.
\end{abstract}

Keywords: hoax news; cognitive and covid-19

\begin{abstract}
Abstrak
Berita hoax dinilai menjadi problematika penting yang sedang dihadapi masyarakat di zaman sekarang. Bersamaan dengan adanya pandemi covid-19, tidak menutup kemungkinan bagi seseorang yang tidak bertanggung jawab untuk menyalahgunakan media sosial guna menebar berita hoax tentang pandemi covid-19 demi keuntungan pribadi. Maka, dalam memahami dan mengolah informasi di media sosial diperlukan cognitive abilities (kemampuan kognitif) yang harus dimiliki oleh setiap individu. Dalam tulisan ini akan diulas mengenai psikologi kognitif, covid-19, serta ciri-ciri dan jenis berita hoax. Kemudian analisis dari tulisan ini adalah menjabarkan bagaimana penerapan pemikiran kognitif dalam mengolah berita hoax selama pandemi covid-19. Hasil dari analisis tersebut adalah agar masyarakat tidak terjebak ke dalam berita hoax, terdapat 3 tahapan pemikiran kognitif dalam mengolah berita hoax selama pandemi covid-19, yang pertama adalah kerangka konsep berpikir dalam melihat sebuah berita, kedua adalah berpikir logis dan kritis dalam menelaah sebuah berita dan ketiga adalah mengambil keputusan atas sebuah berita.
\end{abstract}

Kata Kunci: berita hoax; kognitif dan covid-19

\section{*Corresponding Author}

99sofiaputri@gmail.com 


\section{Pendahuluan}

Pada zaman sekarang teknologi internet bukan hal yang asing lagi ditelinga masyarakat. Jika pada zaman dahulu internet hanya bisa digunakan untuk menukar informasi hanya sebatas melalui email chatting serta menggunaknnya untuk pencarian yakni google browsing (Siti Nurhalimah, dkk, 2019). Namun sekarang internet dapat digunakan lebih dari itu. Dalam hal ini internet dapat digunakan untuk menjawab kebutuhan masyarakat dengan sistem jaringannya. Semua orang dapat memanfaatkan internet untuk mencari informasi baik dari dalam dan luar negeri, serta dapat bekomunikasi dan berinteraksi, belajar, dan berbagai kebutuhan lainnya dapat diakses melalui internet. (Siti Zulfa, 2018).

Contoh adanya bentuk perkembangan dari teknologi internet zaman sekarang adalah diwujudkan dengan adanya berbagai fitur internet media sosial yang disebut dengan medsos seperti facebook, Instagram, Whatssapp dan fitur-fitur lain. Namun, dari berbagai kelebihan media sosial, tentu ada kekurangan media sosial yang dirasakan masyarakat. Salah satu kekurangannya adalah, adanya berbagai berita hoax yang tersebar dengan mudah di media sosial. Dengan adanya kemudahan yang disediakan media sosial dalam membagikan informasi, maka hal ini dimanfaatkan oleh beberapa orang untuk memberikan informasi palsu di media sosial demi keuntungan pribadi (Aspikom, 207).

Terlebih ketika musibah virus covid-19 tengah melanda Negara Indonesia. Pemerintah membuat kebijakan dengan mengadakan PSBB yaitu Pembatasan Sosial Berskala Besar untuk memutus rantai penyebaran virus covid 19 (Elston, 2020). Semua kegiatan baik pembelajaran, pekerjaan dilakukan secara online melalui media sosia 
yang memanfaatkan teknologi komunikasi dengan melalui media sosial (Rusyana \& Supriyadi, 2020). Ditengah situasi yang dirasakan cukup genting tidak sedikit informasi tentang virus covid 19 yang tersebar melalui media sosial Wa, facebook dan Instagram.

Sejak bulan Maret 2020 hingga sekarang pemerintah menghimbau untuk melakukan semua kegiatan secara daring (dalam jaringan) atau virtual melalui media sosial. Dikarenakan semua kegiatan dilakukan secara daring, maka setiap orang memiliki waktu yang relatif banyak untuk menggunakan media sosial. Banyaknya waktu yang digunakan untuk bermedia sosial, tidak menutup kemungkinan bagi seseorang untuk memanfaatkan hal ini dengan membuat informasi menarik atas masalah yang tengah terjadi yaitu informasi tentang virus covid 19.

Banyaknya berita hoax tentang covid 19 dapat menimbulkan kesulitan di masyarakat dalam memilah informasi yang valid dan informasi yang hoax. Problematika ini tengah dirasakan oleh warga Kampung Santren di Surabaya. Para warga Kampung Santren di Surabaya mengaku bingung dalam menghadapi virus covid 19 yang sedang melanda di Negara Indonesia. Karena terlalu banyak berita simpang siur di grup WA Kampung santren. Informasi yang beredar di WA grup Kampung meliputi, "cara penyembuhan covid melalui obat dexametason", "penularan covid melalui tatapan atau handphone", "hewan yang dapat menularkan virus covid", "penyemprotan penangkal virus covid dari udara di Surabaya selatan" serta beragam berita lain yang berniat memberi informasi tetapi malah semakin membuat panik warga.

Terlebih di Kampung santren terdapat salah satu warga yang meninggal dunia karena terdeteksi positif virus covid 19. Banyaknya jenis berita yang tidak tahu sumber dan kebenarannya tersebut beredar 
di WA grup para Ibu-ibu Kampung Santren Surabaya. Terkadang tidak sedikit ibu-ibu yang mempercayai berita yang ada di grup WA Kampung Santren. Karena saat ini pengguna internet dan media sosial umumnya jarang mencerna informasi dan menelusuri terlebih dahulu berita yang ia sebarkan di media sosial (Sumadiria, 2016).

Dalam hal ini sebaiknya warga Kampung santren Surabaya perlu memahami kerangka berpikir psikologi kognitif dalam menyaring beritaberita yang beredar, agar tidak sembarangan dalam menyebarkan berita hoax selama pandemi covid-19 ini. Terkait dengan hal tersebut adanya psikologi kognitifistik berupaya memainkan perannya dalam memberikan pemahaman kepada para pemebaca bagaimana mengolah, memilah informasi yang baik dan benar berdasarkan kerangka berpikir. psikologi kognitifistik adalah cabang ilmu psikologi yang berfungsi untuk pengolahaan, penataan dan penggunaan pengetahuan (Muhibbin, 2005).

Teori Kognitif ini akan melibatkan proses berpikir yang menyeluruh atau kompleks (Nugroho, 2015). Maka dalam tulisan ini akan mengulas peran psikologi kognitifistik untuk mecerna berbagai macam berita selama pandemi covid-19. Ruang lingkup pembahasan dalam tulisan ini meliputi bagaimana kerangka berpikir psikologi kognitifistik, berita hoax di media sosial, serta penerapan psikologi bagaimana peran psikolgi kognitifistik dalam mengolah berita hoax terkait dengan musibah pandemi covid-19 ini di Kampung Santren Surabaya.

\section{Psikologi Kognitif}

Kosa kata kognitif merupakan adjektiva yang berasal dari nomina cognition yang padanannya ke knowing berarti mengetahui. dalam arti yang luas kognitif dan kognisi ialah perolehan penataan dan penggunaan 
pengetahuan dalam perkembangan selanjutnya istilah kognitif menjadi populer sebagai salah satu domain atau wilayah ranah psikologis manusia yang meliputi setiap perilaku mental yang berhubungan dengan pemahaman pertimbangan pengelolaan informasi pemecah masalah kesengajaan dan keyakinan (Muhibbin, 2016 \& 2018).

Kecakapan kognitif adalah kecakapan untuk berpikir secara kompleks serta kemampuannya melakukan penalaran dan problem solving. Kemampuan kognitif akan berkembanga dan akan memudahkan anak menguasai pengetahuan-pengetahuan umum yang ada di lingkungan dan sekitarnya secara lebih luas dan dalam (Ekawati, 2019). Sehingga seorang akan mampu melakukan tujuannya secara baik di dalam berinteraksi bersama orang lain dan kegiatan sehari-hari. Bisa di simpulkan, perkembangan kognitif merupakan perkembangan dari salah satu konsep perkembangan seorang yang berkaitan dengan kegiatan intelektual dan bagaimana mempelajari dan memikirkan lingkungan sekitarnya secara lebih kompleks (Desmita, 2017).

Aspek kognitif merupakan bagian terpenting dari sains kognitif. Karena telah memberi kontribusi yang sangat besar dalam perkembangan psikologi pendidikan dan psikologi belajar. Aspek kognitif merupakan himpunan disiplin ilmu yang terdiri atas psikologi kognitif, ilmu komputer linguistik, intelegensi buatan, matematika, epistimologi, dan neuropsikologi atau ilmu psikologi saraf. Dalam pandangan para ahli kognitif, pendekatan psikologi kognitif lebih menekankan arti pentingnya proses internal mental manusia. Tingkah laku manusia yang terlihat tidak dapat di ukur dan diterapkan tanpa melibatkan proses mental seperti motivasi, keyakinan dan sebagainy. (Thalib, 2010). 
Aspek kognitif merupakan salah satu aspek terpenting. Karena, kognitif berpusat pada otak, maka psikologi kognitif merupakan sumber dan pengontrol aspek-aspek kejiwaan lainnya yaitu aspek afektif rasa dan aspek psikomotor karsa. Beda dengan organ-organ tubuh yang lain, otak adalah sebagai kunci dari aspek kognitif yang tidak hanya menjadi stimulus dan respon dari aktivitas atau pikiran saja. Tetapi juga sebagai alat pengontrol dari aktivitas indra dan tindakan. Berguna sebagai alat pengontrol siang dan malam, jika terjadi kerusakan pada otak, secara psikologis, maka hal itu akan berpengaruh ke organ-organ tubuh lainnya (Tohirin, 2008).

Pembahasan tentang kognitif tentu tidak terlepas dari seorang tokoh yang memprakarsai teori kognitif yaitu Jean Piaget. Piaget adalah tokoh psikologi kognitif yang berasal dari Prancis. Piaget mengatakan bahwa seseorang yang aktif dalam melihat dan menganalisis realitas, maka seseorang itu tidak akan menerima begitu saja jika ada informasi atau berita yang diperoleh. Meskipun kerangka berpikirnya sudah terkonsep dan termordifikasi dengan pengalamannya dalam melihat realita. Tetapi hal tersebut tidak akan merubah keaktifan kerangka berpikirnya dalam mengindentifikasi informasi yang didapat (Galotti, 2017).

Piaget berkeyakinan bahwa pemikiran manusia akan terus mengalami perkembangan melalui beberapa tahapan yang akan terus berproses hingga komples. Berdasarkan teori piaget, setiap manusia akan melewati proses-proses kualitatif. Proses-proses kualitatif itu disebabkan agar setiap manusia dapat beradabtasi dengan orang disekitarnya serta dapat mengorganisasi struktur berpikirnya. Dalam hal ini piaget menggunakan istilah dalam teorinya yaitu "skema" dan "adaptasi", yang pada akhirnya ia mendefinisikan teori kognitifnya 
adalah merupakan sistem kerangka berpikir manusia yang akan terus terstruktur dan beradaptasi dengan lingkungan dan realitasnya (Sternberg, 2008).

Dalam teorinya piaget berasumsi bahwa kemampuan kognitif juga dapat mengatur stimulus tingkah laku seorang manusia. Jika setiap manusia memiliki kecakapan kognitif, maka seseorang tersebut dapat membentuk pengetahuannya sendiri tentang realitas kehidupan di dunia. Piaget berpendapat bahwa setiap anak mempunyai peran yang aktif dalam menstruktur keingintauhannya tentang lingkungan dan realitasnya. Sehingga setiap orang tidak hanya bersikap pasif saat memperoleh informasi baik dari pengalamannya dan diaplikasikan untuk konsepsi kedepannya (Ormrod, 2009). Terdapat tiga tahapan dalam melakukan pemikiran kognitif yaitu:

1. Pembentukan Kerangka Konsep Berpikir

Membentuk konsep berpikir artinya membentuk representasi mental ke dalam sistem yang paling mudah dan mengekspresikannya dengan satu kata seperti contoh bunga tanaman, gajah hewan dan lain-lain. Konsep juga dapat didefinisikan sebagai seperangkat ide yang dituangkan dalam beberapa kata. Membentuk sebuah konsep berpikir adalah perlu memperlibatkan proses berpikir dan memahami. Konsep dipahami sebagai pemahaman yang dalam terhadap suatu hal. Pemahaman yang mendalam ini mengahruskan individu untuk mengkaitkan hal satu dengan yang lainnya secara tepat (Carey, 2000).

Pembehasan mengenai konsep tidak terlepas dengan teori yang terkait dengan terbentuknya konsep yaitu prinsip asosiasi. Dalam prinsip asosiasi mengatakan bahwa pembentukan konsep adalah berasal dari dua hal yaitu pertama memberikan pasangan yang benar 
antara stimulus dan respon kemudia mengindentifikasinya menjadi sebuah konsep. Kedua tidak memasangkan dengan tepat antara stimulus dengan respond dan mengidentifikasinya menjadi sebuah konsep (Zirbel, 2014).

2. Berpikir Logis

Berpikir merupakan sebuah tindakan umum untuk mendeskripsikan sesuatu hal di dalam setiap otak manusia. Sedangkan logika atau logis merupakan ilmu berpikir. Berpikir dan logika adalah satu kesatuan subjek sejak lama. Aristoteles menemukan suatu proses berpikir yang disebut dengan silogisme. Dalam silogisme seseorang dapat berpikir melalui 3 tahapan premis mayor, premis minor, dan konklusi. Kesimpulan akan didapatkan jika proses berpikir silogisme sudah diakui kebenarannya, serta premis yang digunakan pun valid dan benar. Maka kesimpulan yang valid ini dapat dijakdikan sebagai argument (AD, 2018).

Terdapat ciri khas dari silogisme dalam pemahaman kognitif adalah menggunakan kemampuan yang mungkin kita dapat untuk mengevaluasi yang dapat dilihat dari bentuknya. Misalnya dengan memakai simbol $\mathrm{X}$ dan $\mathrm{Y}$ sebagai subjek dan predikat yang memungkinkan pemikiran logis huruf-huruf tersebut menjadi jenis dari matematik aljabar. Kesimpulan yang diperoleh berdasarkan proses pemikiran yang disebut dengan berpikir deduktif. Deduktif adalah teknik berpikir logis yang diperoleh dari gambaran-gambaran prinsip dasar (Slavin, 2011).

3. Pengambilan Keputusan.

Berdasarkan aspek psikologi kognitif, pengambilan keputusan adalah tahapan kognitif yang akan menghasilkan pemilihan keyakinan baik tindakan atau kesimpulan suatu hal berdasarkan beberapa 
kemungkinan. Pengambilan keputusan adalah sebuah hasil akhir yang mungkin akan menuangkan hasil pikiran tersebut ke sebuah tindakan. Pengambilan keputusan bukan persoalan mudah, seseorang harus terlebih dahulu menganalisis dan mengidentfikasi berdasarkan nilai, preferensi, dan keyakinan (Reed, 2011). Berdasarkan psikologi kognitif, hal utama dari pengambilan keputusan selalu melibatkan berbagai alternative dan hasil akhir dari pengambilan keputusan menjadi rencana yang akan dirumuskan berkelanjutan (Triantaphyllou, 2000).

Dalam proses pengambilan keputusan terdapat beberapa karakteristik diantaranya: (1) menentukan tujuan, mengklasifikasikan tujuan dan menempatkannya sesuai urutan prioritas, (3) mengembangkan tindakan alternatif, (4) mengevaluasi alternatif-alternatif berdasarkan tujuan, (5) menentukan keputusan tentatif, (6) mengevaluasi keputusan tentatif untuk kemungkinan konsekuensi yang lebih besar, (7) menentukan tindakan, dan (8) menentukan tindakan tambahan sebagai counter atas konsekuensi yang merugikan (Monahan, 2000).

\section{Berita Hoax di Media Sosial}

Secara umum definisi informasi menurut studi kepustakaan adalah "Suatu peristiwa fenomena yang diamati seseorang, atau bisa juga berupa kesimpulan-kesimpulan yang dibuat seseorang". (Adi 2018). Maka informasi dalam hal ini bisa bersifat hal yang positif dan negative, atu bahkan mungkin bisa saja disusun menjadi informasi yang bersifat hoax, hal ini tentunya bergantung pada kepentingan sang pembuat informasi. Media sosial memiliki dua kata yaitu media dan sosial. Media bermakna sebuah benda yang berfungsi untuk komunikasi. Sedangkan 
sosial adalah suatu tindakan dan interaksi dari seseorang dalam lingkungan sekitarnya (Yusup, 2009).

Jadi media sosial adalah suatu wadah dalam jaringan yang berfungsi sebagai interaksi dalam internet yang penggunaannya untuk mencari dan bertukar informasi dengan berbagai fitur yang ada. Dengan adanya media sosial ini masyarakat dengan mudah dapat bertukar informasi dan aktivitas lainnya tidak perlu bertemu langsung.

Berdasarkan sejarahnya, kata hoax pertama kali trend pada pertengahan tahun abad 18 hingga akhir abad ke 18. Secara umum kata hoax bermula dari kata-kat yang sering digunaka oleh seorang pesulap yaitu "hocus pocus". Gabungan kata "hocus pocus" diambil dari nama sang pesulap sendiri yang sering kali ia memberi julukan pada dirinya sendiri dengan nama "The Kings Majecties Most Excellent Hocus Pocus". Karena setiap kali ia tampil selalu menggunakan berbagai macam trik sulap dengan mengucapkan "hocus pocus, tontus talontos, vade celertier jubeo" sebagai mantranya (Fadli, 2018).

Terdapat seorang pesulap lain dengan menggunakan kata yang sama tapi dalam frase yang berbeda yaitu "hax pax deus adimax". Pada dasarnya frase-frase yang digunakan beberapa para pesulap merupakan peniruan dari frase yang diucapkan dan digunakan oleh imam-iman gereja yang ada di Roma dalam prosesi transubstansi yaitu "hoc est corpus". Berdasarkan hal tersbut maka yang dimaksud dengan kata hoax disini adalah penipuan pada publik atau penipuan pada khalayak (Rahadi, 2017).

Maka definisi dari hoax adalah berita palsu, baik itu berita postif ataupun negatif yang dibuat seakan-akan informasi tersebut benarbenar terjadi. Hoax mempunyai sifat kesengajaan dari pihak yang membuat informasi, hal ini bertujuan untuk kepentingannya diri sendiri. 
Menkominfo (Mentri Komunikasi dan Informatika) Rudi Antara mengemukakan bahwa "hoax adalah dapat diumpakan sebagai penipu, dan juga korupsi informasi". Maksudnya adalah seorang penebar berita hoax dapat dikatakan sebagai penipu dan penyalahgunaan informasi. Karena seorang penebar berita hoax tidak memiliki rasa tanggung jawab (Sutarso, 2019).

Seperti fatwa yang dibuat oleh Majelis Ulama Indonesia (MUI) yang tertera dalam pada tahun 2017 tentang Hukum dan Pedoman Bermuamalah melalui Media Sosial bahwa menggunakan media sosial atau media digital ditengah-tengah masyarakat luas terakdang kerap kali tidak orang-orang tidak memiliki rasa tanggung jawab sehingga kerap kali sosial media menjadi sarana untuk menyebarkan berita palsu yang tidak benar-benar terjadi, fitnah, namimah, ghibah, gosip, memutarbalikkan fakta, hal ini menyebabkan disharmonisasi sosial.

Dalam hal ini tindakan terpenting dalam penanggulangan hoax adalah setiap pengguna media sosial harus mempunyai rasa sadar dan tanggung jawab atas segala perbuatannya, baik itu berupa kata-kata yang dilontarkan ataupun saat menebar fitnah dan membuat kebihan di media sosial. Hoax sama saja seperti dusta yang membawa pada perbuatan negative yaitu kejahatan yang tidak ada manfaatnya sama sekali (Rahadi, 2017).

\section{Metodologi Penelitian}

Penelitian ini menggunakan pendekatan kualitatif. Penelitian kualitatif merupakan peneltian yang memiliki sifat natural, karena seorang peneliti akan melakukan penelitian secara alamiah (Moleong, 2001). Oleh karena itu penelitian secara alamiah ini digunakan untuk mengambil data di lapangan tentang informasi hoax tentang covid 19 
yang terjadi di Kampung Santren Surabaya. Penelitian ini termasuk ke dalam penelitian lapangan field research, selain mengambil data di lapangan. Peneliti juga menggunakan library research sebagai bahan penunjanga pada topic yang diambil. Pokok pembahasan dalam penelitian ini terkait dengan konsep dari psikologi kognitif, serta penerapannya dalam menanggulangi berita hoax yang terdapat di Kampung Santren Surabaya. Teknik pengumpulan data yaitu melalui wawancara dan observasi pada platform media sosial warga, termasuk grup WA Kampung Santren Surabaya (Azwar, 2004).

\section{Hasil Penelitian}

\section{Berita Hoax Covid 19 Melalui Media Sosial di Kampung Santren Surabaya}

Pada dasarnya Kampung santren terdiri dari dua wilayah yaitu wilayah Gang. Langgar dan Gang. Masjid. Kedua wilayah gang ini menjadi satu kesatuan, baik RT, RW dan Kelurahannya menjadi satu. Para warga menyebut dua wilayah ini "Kampung Santren", sebutan ini sudah ada sejak dahulu dari para leluhur untuk kampung warga santren, para warga kampung sebelah pun menyebut kampung ini sebagai kampung santren. Karena, dimana kampung ini sejak dulu hingga sekarang adalah sebuah tempat pusat mengaji dan belajar al-Quran untuk para warga, baik dari warga santren sendiri ataupun dari warga luar kampung santren (Qoyyum, 2020).

Terkait adanya covid 19, kampung santren menjadi salah satu kampung yang saat ini sedang panik karena covid 19, terlebih di wilayah gang masjid terdapat seorang bapak paruh baya yang meninggal dunia, sebab vonis terkena positif covid 19 oleh pihak rumah sakit setempat. Maka secara otomatis kampung santren terkena lockdown selama 
kurang lebih dua minggu. Berdasarkan masalah tersebut maka segala rumor dan informasi merebak di kampung santren terkait pandemi. Hal ini membuat para warga khususnya ibu-ibu jadi selalu rutin mencari berita tentang informasi covid 19 di facebook, kemudian di bagikan di WA grup kampung.

Ibu-ibu Kampung Santren yang bisa memainkan media sosial tidak melihat dan menelisik terlebih dahulu berita yang di peroleh. Hal ini terlihat ketika para ibu-ibu dengan mudahnya membagikan berita yang diperoleh, terkadang informasi yang dishare bersifat meremehkan soal virus covid 19 seperti "Virus Covid 19 Hanyalah Bisnis, Kita Sebagai Orang Islam Jangan Terkcoh Dan Harus Percaya Kepada Allah", ada berita yang membuat panik seperti "Virus Covid Bisa Menular Melalui Tatapan Mata", "Bahaya Penggunaan Android Bisa Menularkan Virus Covid", "Thermo Gun Dapat Merusak Otak", "Makan Bawang Putih Bisa Cegah Virus Covid 19”, Mengkonsumsi “Dexametason Dapat Menangkal Virus Covid 19" (Sumber WA Grup Kampung Santren). Jika seseorang tidak menyaring dan tidak kritis menghadapi berita covid 19 yang simpan siur, maka hal ini akan menjadi sebuah persoalan, semua berita baik yang hoax dan tidak hoax akan diikuti dan di bagikan kepada orang lain lagi.

\section{Penerapan dan Hasil Psikologi Kognitif Dalam Mengolah Informasi Hoax Di Media Sosial Selama Pandemi Covid-19}

Informasi hoax dinilai menjadi problematika yang penting yang sedang dihadapi masyarakat di zaman sekarang. Bersamaan dengan adanya pandemi covid-19 sekarang, tidak menutup kemungkinan bagi seseorang yang tidak bertanggung jawab untuk menyalahgunakan media sosial untuk menebar berita hoax tentang pandemi covid-19 demi keuntungan pribadi informasi hoax semakin mudah dibuat untuk 
membuat panik masyarakat. Informasi hoax semakin lama menjadi semakin berkembang dan berinovasi seiring dengan perkembangan teknologi dan informasi (Tim Humas Kemendag, 2016).

Berdasarkan beberapa penelitian menyebutkan bahwa kecakapan mengindentifikasi informasi yang ada di media sosial dipengaruhi oleh kemampuan cognitive abilities (kemampuan kognitif) yang dimiliki oleh setipa individu. Kemampuan kognitif adalah kecakapan seseorang untuk berpikir secara rasional yang tercakup dari aspek pengetahuan, pemahaman, penerapan, analisis dan evalusai (Siti Rahmi 2015). Selain itu kecakapan kognitif juga diartikan sebagai the processes of thinking, yaitu pengetahuan seorang individu yang diperoleh dari tahapan berpikir individu baik itu tentang seseorang atau tentang sesuatu. Tahapan yang diperoleh adalah pengetahuan dan menyusun pengetahuan berdasarkan kegiatan mengingat, menganalisis, memahami, menilai, menalar, membayangkan dan berbahasa (Morris , 1988).

Informasi hoax yang tersebar di tengah adanya pandemi covid-19 ini dapat membuat panik masyarakat. Khususnya untuk masyarakat yang tidak mencerna dan menganalisis terlebih dahulu informasi tersebut, langsung diterima mentah-mentah tanpa mengindentifikasi lebih jauh tentang keasliannya seperti yang terjadi di Kampung Santren Surabaya. Maka dalam menghadapi informasi hoax di media sosial di tengah pandemi covid-19 masyarakat perlu memiliki kemampuan kognitif untuk mengolah sebuah informasi yang benar dan hoax. Karena kecakapan kognitif seseorang akan sangat mempengaruhi bagaimana tindakannya di media sosial (Gumilar dkk, 2017).

Termasuk bagaimana tindakan dan sikapnya dalam menerima dan mengolah sebuah berita atau informasi. dalam hal ini dapat 
diklasifikasikan menjadi dua tipe pembaca berita yaitu (Tim Humas Kemendag, 2016): 1) Seorang pembaca berita yang memiliki keyakinan penuh atau bisa memebedakan atas adanya informasi berita hoax dan berita informasi yang benar. 2) Seorang pembaca yang ragu akan adanya kebenaran informasi hoax (Rahmawati dkk, 2020).

Klasifikasi pembaca diatas berdasarkan hasil Cognitive Reflection Test (CRT). Berdasarkan hasil riset banyak informan memiliki cara berpikir dalam menanggapi berita secara cepat, spontan tanpa melihat aspek-aspek yang terkait dengan detail. Pada dasarnya dalam konteks berpikir yang bersifat analitis dan kritis model berpikir spontan dan reflek cenderung sangat lemah dalam menganalisis dan membentuk pertimbangan yang jangka panjang. Sehingga tidak heran jika banyak masyarakat atau pembaca berita yang mudah termakan dengan berbagai opini subjektif dari berita-berita yang beredar di media sosial. Maka Agar masyarakat tidak terjebak oleh berita hoax, terdapat 3 tahapan pemikiran kognitif dalam mengolah informasi hoax selama pandemi covid-19 (Ardial, 2014).

Ketua RT mengatakan bahwa hoax memang harus dilawan bersama, ketua RT juga telah mempunyai upaya dalam menanggulangi adanya berbgai macam berita yang dibagikan oleh warga di WA grup Kampung Santren dengan memberikan edukasi pengarahan melalui grup WA, karena covid 19 maka ketua RT tidak bisa mengadakan pertemuan, maka alternatifnya melalui WA grup Ketua RT dapat memberikan pengarahan meliputi berbagai hal seputar: pertama, Penggunaan media sosial yang baik. Kedua, Melakukan upaya memasukkan seorang bidan atau tenaga medis ke dalam Grup Kampung yang dapat memberikan edukasi seputar covid. Ketiga, Terdapat perangkat kelurahan dimasukkan ke dalam grup untuk memantau 


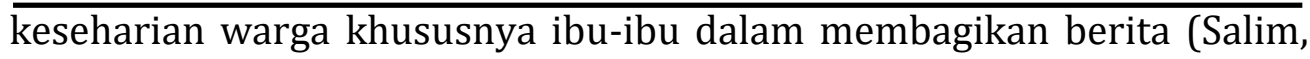
2020).

Keempat Menjelaskan bagaimana ciri-ciri, jenis dan arus persebaran Informasi hoax. Memilah antara informasi hoax dan informasi yang tidak hoax dapat dikatakan sebagai hal yang sulit. Apalagi untuk orang-orang yang buta akan pemahaman media sosial pasti akan menerima dan menelan mentah-mentah semua berita yang ada. Sudah diketahui bahwa informasi hoax adalah suatu informasi kebohongan dan menipu. Tetapi, cybermedia tidak kehilangan taktik mereka menggunakan seribu cara sehingga masyarakat bingung dalam memilah berita hoax dengan berita yang tidak hoax, kemudian masyarakat akan mudah terjebak dalam lubang kebohongan (adila dkk, 2019).

Maka dalam hal ini David Harley, director of malware intelligence dalam karyanya yaitu Common Hoaxes And Chain Letters mengemukakan beberapa cara dalam membedakan informasi hoax, sebagai berikut: 1) Pesan berita mempunyai sifat berantai seperti "jangan berhentin di anda, sebarkan dan anda tidak akan terkena musibah". 2) Tidak menambahkan tanggal kejadian secara jelas agar pembaca tidak bisa meneliti dan mengkonfirmasi lebih lanjut berita tersebut. Contohnya kata "kemarin" dan "dikeluarkan oleh" adalah kata yang tidak mempunyai kejelasan dan kevalidan. 3) Memberi pernyataan bahwa berita yang dibuat adalah bukan penipuan atau berita bohong. 4) Tidak tertera tanggal kadaluarsa berita tersebut. 5) Memberi kutipan organisasi, atau nama tokoh dan link yang tidak ada keterkaitannya dengan konten berita yang disebarkan dan tidak bisa dikonfirmasi (Rayani \& Nur, 2020).

Sedangkan terdapat beberapa jenis hoax, hal ini dikemukakan oleh situs hoax buster yang menyebutkan ada tiga jenis hoax yaitu (Aspikom, 2017): 1) Hoax hadiah, adalah hoax yang memberikan sejumlah hadiah. 
Tentu ini hadiah ini hanyalah bersifat iming-iming, penipuan dan kebohongan. 2) Hoax simpati adalah hoax dengan membuat berita kebohongan tentang orang yang sakit, orang yang kesusahan sedang membutuhkan bantuan. Tujuannya adalah untuk meminta sumbangan palsu pada masyarakat. 3) Urband Legend, menyebarkan berita palsu tentang sesuatu barang, benda atau hal yang belum jelas kebenarannya. Seperti contoh bedak bermerk mawar dapat memutihkan secara permanen.

Berbagai jenis hoax di atas dapat dibuat dan disebar oleh orangorang yang memiliki pemahaman dalam membaca berita hanya sesuai sudut pandangnya saja, tidak memiliki pemikiran yang terbuka serta tidak memiliki rasa tanggung jawab. Orang-orang ini tidak perduli dengan realita yang sebenarnya, mereka akan menuntut orang lain untuk percaya pada apa yang mereka inginkan.

Arus Penyebaran Hoax Dalam hal ini dapat diklasifikasikan arus penyebaran informasi hoax menjadi empat hal yaitu (Ardial, 2014): 1) Kedalaman (Depth), dapat dilihat dari jumlah loncatan sharing berita atau persebaran berita. 2) Ukuran (Size), dapat diketahui melalui jumlah pengguna media sosial yang terlibat dalam arus berita tersebut. 3) Cakupan maksimum (Maximum Breadth), dapat diketahui dari jumlah pengguna media sosial yang terlibat dalam skala wilayah yang lebih luas. 4) Strukturalitas viral (Structural Virality), dapat diketahui dari salah satu siaran dalam siaran besar dan teru tersebar secara berulang-ulang secara utuh dari lintas saluran satu ke yang lain.

Seperti yang dikatakan oleh Edwin Diamond (1980) banyaknya informasi hoax diperburuk dengan keadaan masyarakat yang cenderung lebih tertarik dengan berita yang bersifat negative. Hal ini membuat pembenaran bahwa informasi yang buruk adalah termasuk informasi 
yang baik (Good News Bad News, 1980). Peristiwa seperti ini terjadi dalam masyarakat dari hasil penklasifikasian menyatakan bahwa informais hoax akan tersebar lebih cepat, dan dalam dibanding dengan berita yang benar. Informasi hoax yang ada di media sosial dianalisis 70\% mudah dibagikan kepada pengguna lain khususnya informasi yang berbau negative. Masyarakat mudah menyebarkannya agar pengguna lain juga ikut mengetahuinya tanpa mempertimbangkan dampak yang dihasilkan.

Salah satu warga yang sudah berstatus ibu rumah tangga mengatakan bahwa ia sering mengambil berbagai informasi melalui facebook, kemudian langsung membagikannya lagi melalui WA grup kampung, dengan maksud ingin memberikan informasi yang didapatkan ke warga lain. Maka dalam hal ini para warga juga diberikan pemahaman untuk bersikap kritis dan menganalisis terlebih dahulu soal informasi yang didapatkan.

Kelima Upaya terakhir yaitu Memberikan contoh dalam menelaah sebuah berita dengan menganalisisnya terlebih dahulu melalui kerangka berpikir, berpikir secara logis dalam membaca berita, mencari sumbernya dan memutuskan berita tersebut layak untuk dibagikan dan dikonsumsi. Pada awalnya dalam melihat sebuah berita warga diharsukan membuat kerangka berpikir dalam menerima sebuah informasi, ditentukan dari dalamnya proses thinking and understanding si pembaca berita. Karena cara berpikir setiap manusia dalam menerima sebuah berita itu berbeda-beda.

Berdasarkan hasil dari cognitive reflection test mengemukakan bahwa seseorang yang mempunyai model berpikir spontan dan cepat mempunyai tingkat analisis yang terbilah rendah. Seperti yang dikatakan oleh teori Razor's Occam bahwa umumnya manusia mempunyai 
kecenderungan konsep berpikir yang sederhana dan simpel. Maknanya kebanyakan orang dalam menghadapi suatu masalah akan lebih memiliki suatu pemikiran yang cepat dan spontan. Pemikiran yang cepat dan spontan akan menghilangkan proses berpikir kognitif secara kompleks (Puspita, 2017).

Sedangkan pembaca yang mempunyai kecakapan yang dilandaskan pada pengalaman dan pengetahuan cenderung mencerna terlebih dahulu informasi yang diterima secara kritis dan analitis. Dengan seperti ini kerangka konsep akan terbentuk dengan jelas dari sebuah informasi tersebut. Berdasarkan hal tersebut pembaca akan melalui proses berpikir yang dalam yaitu memahami (understanding) dan proses bepikir (thinking process) dari sebuah berita (Reed, 2011). Seperti contoh terdapat seseorang menerima sebuah berita tentang covid 19 bahwa "Covid Hanyalah Sebuah Bisnis Belaka”.

Jika seorang pembaca memiliki kerangka konsep berpikir yang jelas dari sebuah informasi. Ia akan mengemukakan pertimbangan dan analisanya, meski kesimpulannya tidak tepat tetapi yang permasalahkan bukan jawaban tepat atau tidaknya. Melainkan melihat sudah sampai mana tingkat analisis dari sang pembaca dalam melihat sebuah realitas. Berbagai teori konspirasi yang bereda karena adanya covid seharusnya masyarakat tidak menelan mentah-mentah semua informasi tersebut. Tetapi menganalisis dari berbagai arah, mempertimbangkan mana informasi yang layak diterima dan informasi yang tidak disebarkan ke orang lain.

Selanjutnya berpikir logis dan kritis dalam menelaah sebuah berita, kecakapan manusia dalam berpikir secara logis juga ada keterkaitannya dengan kecakapan kognitif. Karena logika selalu berkaitan dengan cara berpikir manusia. Banyak pembaca berita yang terjebak oleh berita palsu 
di media sosial tidak terkecuali warga Kampung Santren Surabaya. Karena pada dasarnya seorang pembaca yang mempercayai informasi palsu tidak memakai pikiran yang logis dalam menelaah sebuah berita. Hal ini dibuktikan dengan tidak menggunakan sikap yang kritis dalam melihat sebuah berita tersebut (AD, 2018).

Tidak bersikap kritis ini yang menjadikan pembaca menerima begitu saja berita dengan apa adanya tanpa adanya pertimbangan secara kompleks. Kemudian dibuktikan dengan pembaca melontarkan pendapat yang bersfiat subjektif tanpa meragukan kevalidan berita yang diterima. Dapat dikatakan bahwa kecakapan penggunaan pemikiran yang logis dengan baik adalah dengan memastikan sejauh mana tingkat kepercayaan pembaca dari sebuah berita atau informasi di sosial media.

Pada dasarnya berpikir logis dan kritis mempunyai kesamaan dengan membuat kerangka konsep. Karena jika pembaca sudah meragukan kevalidan berita, maka pembaca sudah memulai menggukan kecakapan logikanya dengan baik. Tanda-tandanya adalah mampu bernalar dan bersikap kritis terhadap sebuah informasi. Maksud dari bersikap kritis adalah pembaca membuat pertimbangan dari berbagai aspek secara proposional, demi mendapatkan kevalidan sebuah berita (Reed, 2011).

Warga Kampung Santren harus dibiasakan dapat berpikir kritis dalam melihat realitas khususnya di media sosial. Karena media bukanlah tempat yang hanya berisi hal postif dan netral, tetapi sebaliknya dalam media juga ada hal neagtif. Media juga digunakan beberapa kelompok tertentu untuk menghasut masyarakat dan mendominasi kelompok lain. Seseorang yang kritis akan melihat struktur sosial sebagai realita. Seorang yang aktif dalam media sosial jika 
$\overline{\text { tidak memperhatikan struktur sosial dia hanya akan bisa mengamati }}$ tanpa memahami dan menganalisis.

Pada dasarnya pemikiran kritis mempunyai sifat kualitatif dan perlu memakai penafsiran sebagai dasar utama dari memberi definisi pada temuan baru dari analisis kritisnya. Jika melihat informasi, seorang yang kritis akan melihat berita dari berbagai sisi dan tidak pernah berpikir bahawa suatu berita itu bersifat netral. Karena media adalah sebuah tempat dari berbagai kelompok yang berusaha menjadi dominan dari kelompok lainnya. Di tengah pandemi covid-19 sebaiknya masyarakat mengkonsumsi berita yang sumbernya sudah jelas. Serta bisa membandingkan berita satu dengan berita lainnya yang dapat dinalar dengan logis.

Kecakapan dalam pengambilan keputusan dinilai sebagai suatu proses dari berpikir kognitif, yang akan menghasilkan pemilihan keyakinan baik tindakan atau kesimpulan suatu hal berdasarkan beberapa kemungkinan. Pengambilan keputusan adalah sebuah hasil akhir yang mungkin akan menuangkan hasil pikiran tersebut ke sebuah tindakan. Pengambilan keputusan bukan persoalan mudah, seseorang harus terlebih dahulu menganalisis dan mengidentfikasi berdasarkan nilai, preferensi, dan keyakinan (Zirbel, 2014).

Pengambilan keputusan ini adalah hasil akhir dari dua tahapan sebelumnya yaitu kerangka formasi dan logika. Oleh karena itu jika para warga belum bisa mensturktur kerangka konsep yang benar dari sebuah berita dan tidak mampu memakai pemikiran yang logis dalam menganalisis kevalidan dari sebuah berita. Maka dapat diketahui mereka akan terperangkap dalam pengambilan keputusan yang tidak tepat dari sebuah berita. Hal ini bisa diketahui dengan adanya tindakan menyebarkan informasi berita tersebut secara langsung atau secara 
$\overline{\text { spontan dalam kurun waktu beberapa saat saat si pembaca sudah }}$ membaca berita tersebut secara sekilas tanpa menelaahnya terlebih dahulu.

Hal ini bisa diketahui dengan adanya sikap pembaca yang enggan untuk menyebarkan berita tersebut secara spontan. Mereka akan cenderung membaca lamat-lamat dan mencari kevalidan isi dari berita tersebut. Dalam hal ini setiap orang haruslah terlebih dahulu menganalisis dari berbagai aspek kemudian baru dapat mengambil keputusan untuk menggunakan berita tersebut atau tidak. Karena pengambilan keputusan ini dinilai menjadi sebuah tindakan yang menentukan dalam bersosial media (Fadli, 2018).

Keenam yaitu warga diharuskan untuk literasi cerdas dalam menelaah sebuah berita. Sering membaca, mencari tahu sumber asalnya dan teliti adalah termasuk dalam melatih daya kognitif. Sebab, dengan bertindak seperti itu kita melatih daya logika, sebelum menetapkan berita valid atau hoax, seorang pembaca harus membaca berita dengan topic yang serupa dari judul satu ke judul yang lain. Maka dari sini dapat dinilai berita yang didapat valid atau berita hoax. Verivikasi tersebut membuktikan apakah berita yang didapatkan berasal dari media yang kredibel dan dapat bertanggung jawab atas berita yang dikeluarkan (Afwiyana dkk, 2019).

Langkah-langkah tersebut telah diterapkan di kampung Santren sejak bulan Agustus hingga sekarang. Warga kampung santren mulai memahami apa yang disebut dengan berita hoax di media sosial. Meski tidak semua warga memahami dan menerapkan kerangka berpikir logis tetapi ada beberapa warga mulai memahami dan memperlihatkan daya kerangka berpikir logis dan kritis dalam menelaah sebuah berita. Hal ini terlihat adanya beberapa warga yang dulunya sibuk mengakses semua 
berita di berbagai platform sosial media dan di bagikan di WA grup Kampung. Namun sekarang para warga tersebut sibuk mencari berbagai berita yang hoax tentang covid 19, kemudian mereka membedakan berita yang valid dan hoax, mencari latar belakang berita yang ditemukan, melihat media yan menerbitkan apakah kredibel dan bisa dipercaya. Kemudian baru membagikannya di WA grup di sertai dengan sumber yang jelas.

Beberapa warga ada yang membagikan berita yang hoax disertai dengan sumber yang jelas pula. Dalam hal ini, grup WA Kampung yang dulunya ramai karena satu sama lain adu argument terhadap sebuah berita. Maka sekarang terlihat lebih tertib dalam merespon dan menelaah sebuah berita. Ketua RT Kampung Santren berharap bahwa warga di Kampung Santren tidak terjebak ke dalam berita hoax. Berharap bahwa para warga mempunyai konsep berpikir kognitif dan kritis, agar nantinya warga dapat lebih berhati-hati dalam bersikap terhadap pengambilan keputusan dari sebuah berita.

\section{Simpulan}

Berdasarkan pemaran penelitian diatas, maka dapat ditarik kesimpulan bahwa Terdapat tiga tahapan dalam melakukan pemikiran kognitif yaitu: pembentukan kerangka konsep berpikir, berpikir logis, dan pengambilan keputusan. Penerapan psikologi kognitif dalam mengelola berita hoax covid 19 di Kampung Santren Surabaya, melalui enam langkah yaitu pertama, Penggunaan media sosial yang baik. Kedua, Melakukan upaya memasukkan seorang bidan atau tenaga medis ke dalam Grup Kampung yang dapat memberikan edukasi seputar covid. Ketiga, Terdapat perangkat kelurahan dimasukkan ke dalam grup untuk 
memantau keseharian warga khususnya ibu-ibu dalam membagikan berita. Keempat Menjelaskan bagaimana.

Ciri-ciri, jenis dan arus persebaran Informasi hoax. Kelima Memberikan contoh dalam menelaah sebuah berita dengan menganalisisnya terlebih dahulu melalui kerangka berpikir, berpikir secara logis dalam membaca berita, mencari sumbernya dan memutuskan berita tersebut layak untuk dibagikan dan dikonsumsi dan Keenam, literasi media. Langkah-langkah tersebut teah diterapkan di wilayah Kampung Santren. Para warga sebagian mulai memahami apa yang disebut dengan berita hoax dan bagaimana menelaahnya. Namun, sebagian lagi sudah menerapkan dan melakukan upaya berpikir kritis dalam menelaah sebuah berita dengan cara mencari sumber asalnya dan meneliti terlebih dahulu media yang menerbitkan berita. 


\section{Daftar Pustaka}

Ardial. (2014). Paradigma dan Model Penelitian Komunikasi, Jakarta: Bumi Aksara.

Aspikom. (2017). Komunikasi di Era Teknologi Digital, Yogyakarta: Himpenindo.

Desmita. (2017). Psikologi Perkembangan Peserta Didik, Bandung: Remaja Rosdakarya.

Diamond, E. (1980). Good News Bad News, Massachusetts: The Massachusetts Institute of Technology.

Galotti, Kathleen, M (2017). Cognitive Development: Infancy Trough Adolescence (Second Edition), CA: Sage Publication. Inc.

Sumadiria, H. A. (2016). Hukum dan Etika Media Massa, Bandung: Simbiosa Rekatama Media.

Monahan, George, E. (2000). Management Decision Making: Spreadsheet Modeling, Analysis, and Application, New York: Cambridge University Press.

Morris, Charles, G. (1988). Psychology: an Introduction, NJ: Prentice Hall.

Nurhalimah, Siti., dkk. (2019). Media Sosial dan Masyarakat Pesisir, Jakarta: Deepublisher.

Ormrod, Jeanne, Ellis. (2009). Educational Psychology Developing Learners Sixth Edition, terj. Wahyu Indiati dkk, Jakarta: Erlangga.

Reed, Stephen, K. (2011). Kognisi: Teori dan Aplikasi, Jakarta: Salemba Humanika.

Sternberg, Robert, J. (2008). Cognitive Psychology Fourth Edition, Terj. Yudi Santos, Yogyakarta: Pustaka Pelajar.

Slavin, Robert, E. (2011). Educational Psychology: Theory And Practice, 9th $E d$, Terj. Marianto Samosir, Jakarta: Hak Cipta Bahasa Indonesia.

Syah, Muhibbin. (2018). Psikologi Belajar. Bandung: Rajawali Press. . (2005). Psikologi Pendidikan Suatu Pendekatan Baru, Bandung: Remaja Rosdakarya.

. (2016). Telaah Singkat Perkembangan Peserta Didi., Jakarta Rajawali Press.

Thalib, Syamsul, Bachri. (2010). Psikologi Pendidikan Berbasis Analisis Empiris Aplikatif. Jakarta: Kencana Prena Media. 
Sofia Zaini Kulbi

Tim Humas, Kemendag. (2016). Panduan Optimalisasi Media Sosial. Jakarta: PHM Press.

Tohirin. (2008). Psikologi Pembelajaran Pendidikan Agama Islam (Berbasis Integrasi dan Kompetensi). Jakarta: Raja Grafindo Persada.

Triantaphyllou, Evangelos. (2000). Multi-Criteria Decision Making Methods: A Comparative Study Applied Optimization. Dordrecht: Kluwer Academic Publishers.

Pawit, M. Y. (2009). Ilmu Informasi, Komunikasi dan Kepustakaan. Jakarta: Bumi Aksara.

AD, Yahya. (2018). Konsep Perkembangan Kognitif Perspektif Al-Ghazali dan Jean Piage. KONSELI: Jurnal Bimbingan dan Konseling (EJournal), 5(2), 97-104. https://doi.org/10.24042/kons.v5i2.3501

Adila, I, Weda, W., \& Tamitiadin, D. (2019). Pengembangan Model Literasi Dan Informasi Berbasis Pancasila Dalam Menangkal Hoax. WACANA: Jurnal Ilmiah Ilmu Komunikasi, 18(1), 101-111. https://doi.org/10.32509/wacana.v18i1.721

Afwiyana, N. D., Amrozi, Y., \& Falihah, T. (2019). Langkah Cerdas Bermedia Sosial Di Kalangan Santri Milenial, Saintekbu: Jurnal Sains Dan Teknologi, 11(2), 39-44. https://doi.org/10.32764/saintekbu.v11i2.361.

Carey, Susan. (2000). The Origin of Concept. Journal of Cognition and Development, 1(1), 37-41. DOI: 10.1207/S15327647JCD0101N_3

Elston, Dirk, M. (2020). The Coronavirus (Covid-19) Pandemi and Patient Safety. Journal of the American Academy of Dermatology, 82(4), 819-820. DOI: 10.1016/j.jaad.2020.02.031

Ekawati, Mona. (2019). Teori Belajar Menurut Aliran Psikologi Kognitif Serta Implikasinya Dalam Proses Belajar Dan Pembelajaran. ETech: Jurnal Ilmiah Teknologi Pendidikan, 7(2), 1-12. https://doi.org/10.24036/et.v7i2.106979

Fadli, Andi. (2018). Etika Dan Tanggung Jawab Jurnalis Studi Pemberitaan Hoax Melalui Media Online di Kota Makassar. Jurnalisa, $4(2)$

181-195.

https://doi.org/10.24252/jurnalisa.v4i2.6893 
Kementrian Komunikasi Dan Infromatika, "Menkominfo: Hoax Itu Seperti Korupsi Harus Diperangi, Official Website Kementrian Komunikasi Dan Informatika Republic Indonesia.

Majlis Ulama Indonesia "Fatwa No.24 Tahun 2017 tentang Hukum dan Pedoman Bermuamalah Melalui Media Sosial", Official Website Majelis Ulama Indonesia.

Ekopriyono, A. (2018). Pendekatan Kritis Menangkal Hoax. Prosiding Semateksos 3. Strategi Pembangunan Nasional Menghadapi Revolusi Industri 4.0. IPTEK Journal of Proceedings Series, 5 290297. http://dx.doi.org/10.12962/j23546026.y2018i5.4448

Ratna, P. (2017). Penjelasan Ilmiah Berita Palsu dan Hoax Menyebar Cepat. Republika online, 02 Juli.

Nugroho, P. (2015). Pandangan Kognitifisme dan Aplikasinya dalam Pembelajaran Pendidikan Agama Islam Anak Usia Dini. ThufuLA: Jurnal Inovasi Pendidikan Islam Anak Usia Dini, 3(2), 281-3014. http://dx.doi.org/10.21043/thufula.v3i2.4734

Rahadi, D. R. (2017). Perilaku Pengguna Dan Informasi Hoax Di Media Sosial. Jurnal Manajemen \& Kewirausahaan, 5(1), 58-70. https://doi.org/10.26905/jmdk.v5i1.1342

Rahmi, S. (2015). Pengaruh Pendekatan Perilaku Kognitif Terhadap Tingkat Penyesuaian Diri Siswa Di Kelas VII SMP Negeri 29 Makassar. Jurnal Psikologi Pendidikan \& Konseling, 1(1), 28-38. https://doi.org/10.26858/jpkk.v1i1.1354

Rayani, D., \& Purqoti, Dewi N. S. (2020). Kecemasan Keluarga Lansia Terhadap Berita Hoax Dimasa Pandemi Covid- 19. Jurnal Realita, 5(1), 906-912.

Rusyana A. Y., \& Supriyadi, D. (2020). Fatwa Penyelenggaran Ibadah di Saat Pandemi Covid-19 di Indonesia Dan Mesir. Perbandingan Mazhab dan Hukum. UIN Sunan Gunung Djati Bandung.

Sutarso, J. (2019). Menggunakan Media Sosial Dengan Bijak Untuk Menghindari Penyebaran Berita Hoax di Kalangan Masyarakat. The $10^{\text {th }}$ University Research Colloqium. Sekolah Tinggi Ilmu Kesehatan Muhammadiyah Gombong.

Zirbel, E. L. (2014). Learning, Concept Formation, and Conceptual Change. Tuft University Journal. 
Zulfah, S. (2018). Pengaruh Perkembangan Teknologi Informasi Lingkungan (Studi Kasus Kelurahan Siti Rejo I Medan). Jurnal online.

\section{Informan:}

Bapak Agus, Salim, ketua RT Kampung Santren Surabaya.

Bapak Qoyyum, Tokoh Agama Islam Kampung Santren Surabaya.

Para Warga Ibu-Ibu Kampung Santren Surabaya. 